\title{
Defoliation Dynamics on Grazing Horizons in Pastures Intercropped by Panicum maximum, Brachiaria brizantha, and Brachiaria decumbens
}

\author{
P. B. Fernandes ${ }^{\mathrm{a}, *}$, R. A. Barbosa ${ }^{\mathrm{b}}$, M. G. Morais ${ }^{\mathrm{a}}$, C. Medeiros-Neto ${ }^{c}$, A. F. Sbrissiac ${ }^{\mathrm{c}}$, H. J. Fernandes ${ }^{\mathrm{d}}$, \\ \& G. S. Difante ${ }^{a}$ \\ ${ }^{a}$ Federal University of Mato Grosso do Sul-UFMS, Campo Grande - 79070-900, MS, Brazil \\ ${ }^{\natural}$ Brazilian Agricultural Research Corporation, Embrapa Beef Cattle, Campo Grande - 79106-550, Brazil \\ 'State University of Santa Catarina-UDESC, Lages - 88520-000, SC, Brazil \\ dState University of Mato Grosso do Sul-UEMS, Aquidauna - 79200-000, MS, Brazil \\ *Corresponding author: zoo.patrick@hotmail.com \\ (Received 26-12-2019; Revised 30-03-2020; Accepted 03-04-2020)
}

\begin{abstract}
The aim of this study was to quantify and verify the defoliation dynamics process of the Panicum maximum, Brachiaria brizantha, and Brachiaria decumbens intercropping during the formation of four grazing horizons in lenient grazing intensities and high grazing intensity. Pastures were managed in a pregrazing height of $70 \mathrm{~cm}$, and as post-grazing height, the criteria of $40 \%$ and $60 \%$ were used in relation to the pre-grazing height. The experimental design used was a completely randomized design with a $3 \times 4$ factorial arrangement. The first factor was the cultivars of intercropped grasses consisted of 3 cultivars, i.e., BRS Zuri, Xaraés, and Basilisk. The second factor was grazing horizons consisted of 4 levels, i.e., I: one; II: two; III: three; IV: four. In the intercropping managed with $40 \%$ of the forage canopy height removal, oscillations were observed in the severity of defoliation of the extended tiller among the intercropped species, in which the tiller reduction of the 'Basilisk' was $32 \%$ lower in relation to 'BRS Zuri'. In the intercropping managed with $60 \%$ of the forage canopy height removal intensity, disproportionality was observed among the grasses, because the 'Basilisk' suffered a higher severity and frequency of pseudostem defoliation. In intercropped pastures managed under grazing intensities of $40 \%$, as the animal explores the grazing horizons, the vertical distribution of the pseudostem could modify the shape and positioning of the depth of the bite, leading the animal to perform less selective grazing among the species. Due to the higher supply of pseudostem mass at the intensity of $60 \%$, it was possible to infer that there was a reduction in forage intake.
\end{abstract}

Keywords: botanical components; frequency of defoliation; pseudostem; severity of defoliation; tiller

\section{INTRODUCTION}

The benefits of different pasture intercropping in an ecosystem are related with the increase of biomass production, nutritional value, and animal productivity (Stejskalová et al., 2013; Duchini et al., 2018) when compared to monoculture pasture (Roca-Fernández et al., 2016; Grace et al., 2018). In the intercropping of forage grasses of a tropical climate, the answers are still unknown, since the defoliation pattern can be strongly influenced by the mixed architecture of the forage canopy, i.e., if the structure of one of the grasses is unfavorable due to the vertical positioning of the tiller and its botanical components, it reduces defoliation, leading to a preference among the intercropped species. This can compromise the productivity and longevity of the diversity in the pasture, so it is necessary to use techniques that can neutralize this possible event.

The grazing intensity may be one of the ways to control the possible effects of the mixed architecture of the forage canopy, considering that the pasture height management is decisive on the morphological charac- teristics of the tiller (Montagner et al., 2012; Menezes et al., 2019). Therefore, it can also determine the possible preference or promote the absence of selectivity in the intercropping of tropical climate grasses.

In heterogeneous perennial pastures, it is possible to verify that the animals may present a greater preference for the dominant grass species in the paddocks. However, it is necessary to consider the effect of grazing intensity, since, in managements with greater grazing intensities, which means less forage supply, the diversity of bites is less. As the animal explores and molds the possible grazing horizons, adjustments can occur in the depth of defoliation and may reduce the selection during grazing, which may result in the consumption of a mixed diet at each grazing cycle (Carvalho, 2013).

In tropical climate pastures, the associative effect of two or more grasses intercropped on the process of diet selection during grazing events is still unknown, thus, for this scenario it is necessary to carry out management proposals that maximize the rate of forage intake and enhance the use of the forage resource 
produced. Therefore, two hypotheses were proposed: (I) in lenient grazing intensities (removal of $40 \%$ of the initial pre-grazing height) grass species with higher population density of tillers are more preferred during the formation of grazing horizons due to greater harvest accessibility, impacting lower utilization efficiency of the forage resource produced; (II) in high grazing intensities (removal of $60 \%$ of the initial pre-grazing height), preferences will not be observed among the intercropping grasses, due to the successive defoliation in the tillers, caused by the high stocking rate. This study aimed to quantify and verify the defoliation dynamics process of the Panicum maximum, Brachiaria brizantha, and Brachiaria decumbens intercropping during the formation of four grazing horizons in lenient grazing intensities and high grazing intensity.

\section{MATERIALS AND METHODS}

\section{Study Site}

The experiment was carried out in the experimental area of Brazilian Agricultural Research Company National Center for Research in Beef Cattle (Located in the city of Campo Grande - MS Lat. 2027' S, Long. $54^{\circ} 37^{\prime} \mathrm{W}$ and altitude of $530 \mathrm{~m}$ above the sea level). The implementation and stabilization of pastures were occurred from September 2016 to February 2018, and the start of evaluations from March 2018 to May 2018. The experimental area had six paddocks, and each paddock had an area of 0.25 hectares (ha). The features related to the climate and precipitation of the experimental site were presented in the work of Fernandes et al. (2020a).

\section{Soil/Pre-experimental Management and Treatments}

The parameters related to soil texture and chemical composition were presented by Barbosa et al. (2018) and Fernandes et al. (2020a). Based on soil analysis in September 2017, it was applied 1 ton/ha of dolimitic limestone in November 2017, $80 \mathrm{~kg} / \mathrm{ha}$ of phosphorus pentoxide and potassium oxide was applied in December, February, and March, the application of 150 $\mathrm{kg} / \mathrm{ha}$ of nitrogen was applied.

The pastures were sown with Panicum maximum cv. BRS Zuri intercropping with two cultivars of Brachiaria spp. (Xaraés and Basilisk). The sowing procedures of the intercropped were described in the work of Barbosa et al. (2018). The sowing rate was based on the germination, expecting a population of 100 plants $/ \mathrm{m}^{2}$ (50 Panicum plants and 25 plants from each Brachiaria). The estimation of plant germination per square meter was based on previous experiments carried out by Barbosa et al. (2018), where a germination rate of $50 \%$ was observed for the genus Brachiaria and $20 \%$ for grasses of the genus Panicum.

After the implantation of the pastures, it was established with pre-grazing height criterion when the forage canopy reached $95 \%$ of luminous interception, i.e., $70 \mathrm{~cm}$ high; from May 2017 to March 2018 pastures were managed at two post-grazing heights (40 to $60 \%$ compared to the pre-grazing height). The grazing inten- sity target was based on the average height of the forage canopy of 'BRS Zuri', since this was the predominant grass in the intercropping. With the aid of a graduated ruler, 60 points were recorded per paddock related to the height of the species of the genus Panicum, allowing a maximum variation of $10 \%$ between the measured height and that specified for each intensity.

Bos taurus $\mathrm{x}$ Bos indicus cows approximately 24 months of age belonging to the EMBRAPA herd were used to reduce the post-grazing height. The adjustment in the stocking rate was based on the expectation of each established post-grazing height.

\section{Forage Mass and Botanical Composition}

In the pre and post grazing, the forage mass was estimated by collecting six samples per paddock. Forage collection was performed by cutting the grass close to the soil, which was contained inside $1 \mathrm{~m}^{2}$ frames. After cutting, the samples were packed in plastic bags and identified. Those were taken to the laboratory and divided into two parts: to quantify forage biomass (Forage mass, leaf lamina, pseudostem [stem + sheath] and dead material), one of the subsamples was destined for the forced air circulation drying oven at $55^{\circ} \mathrm{C}$ until reaching a constant weight; before starting botanical separation of the samples, the identification and count of the tillers of each grass was performed according to their respective grazing intensities.

\section{Height and Horizontal Distribution of Intercropping Grasses}

In the pre-grazing, the spatial distribution of cultivars and their respective botanical components were quantified along with the vertical profile of the forage canopy. An average of 300 observations was performed in each grazing intensity, by the inclined point quadrat method (Brunetti et al., 2016). The device was allocated in points that represented the average canopy height at the time of sampling. The wooden stem was inserted into the canopy, and its pin touched the different plant structures and tissues of all grasses. Therefore, the botanical components were identified: expanding leaf lamina, expanded leaf lamina, pseudostem, and dead material. After each touch, the component was carefully removed from the pin to continue the evaluation process that introduced the graduated rod into the canopy until a new touch occurred. This procedure was repeated until the pin touched the ground, generating the last reading of height.

\section{Defoliation Pattern}

To detect the oscillations in the defoliation pattern during the lowering period of the pastures, the technique of marked tillers was used (Miqueloto et al., 2020). For this measurement, during the pre-grazing, 45 vegetative tillers were marked per paddock, 15 of each grass of the intercropping, identified, and distributed in equidistant points. The identification of each tiller was performed by means of colored ribbons. The measure- 
ments of the extended tiller, the distance between the soil and the apex of the highest leaf when positioned vertically and pseudostem, and the distance between the soil and the gland of the last completely expanded leaf lamina, were all taken with the aid of a graduated ruler. After the pre-grazing evaluations, the animals had access to paddocks, and every two days, the evaluations of the extended tiller and pseudostem of each grass were performed again, classified as an intact or defoliated (When the reduction related to the previous evaluation occurred).

\section{Severity and Frequency of Defoliation}

From these measurements, the severity of defoliation (plant tissue removed at each touch) was quantified according to the following formula: severity $(\%)=\left[\left(\right.\right.$ ini- $^{-}$ tial length-final length) / initial length]. The frequency of defoliation was calculated from the following formula: frequency $(\%)=$ number of touches observed in each grass $\div$ total number of marked tillers $\div$ interval between horizon formation (Days) (Adapted from Fernandes et al., 2020b).

With the reduction of the length of the tiller, it was verified that grazing horizons could occur (Fernandes et al., 2020b; Figure 1). Therefore, it was assumed that the horizons evaluated would be a source of variation that could modify the defoliation process, or even the preference among the cultivars intercropped. Therefore, as a new grazing horizon formed, a new evaluation cycle began. For that reason, each grazing intensity was analyzed within four grazing horizons, in each paddock. Grazing horizons can be interpreted as follows: horizon I was day zero to the second day of grazing, horizon II was second day to the fourth day of grazing, horizon III was fourth day to the sixth day of grazing, and horizon IV was sixth day to the eighth day of grazing.

\section{Statistical Analysis}

Descriptive analysis to characterize the forage canopy, the data of height, forage mass (leaf lamina, pseudostem, and dead material), the population density of tillers, and stocking rate was grouped into means and percentages. According to the recommendation of Brunetti et al. (2016), the inclined point data were transformed into percentages and plotted into figures.
For the analysis of defoliation dynamics data, 36 observations were quantified for each grazing intensity. The data were submitted to variance analysis, within each defoliation intensity, according to an entirely randomized model, in the factorial arrangement:

$Y i j k=\mu+I G i+G H j+\left(I G^{*} G H i j\right)+\varepsilon i j k$

where, Yijk was the observed value; $\mu$ was the general constant; IGi was the effect of the intercropped grasses ( $i=$ BRS Zuri, Xaraés and Basilisk); GHj was the effect of grazing horizon ( $j=\mathrm{I}$ : one; II: two; III: three; IV: four); $\mathrm{IG}^{*} \mathrm{GHij}$ was the effect of the interaction between intercropped grasses (IGi) and grazing horizon (GHj); and eijk was the random error associated with each observation i, j and k. When appropriate, Tukey's mean comparison test was performed, and a 5\% significance level was considered. For the analyses, the ExpDes package (Ferreira et al., 2014) of the software R was used.

\section{RESULTS}

\section{Structure of the Forage Canopy}

The mean height of the forage canopy in the pregrazing was $71 \mathrm{~cm}$ in both grazing intensities, and approximately $50 \%$ of forage mass was composed of leaf lamina mass. Moreover, after the stabilization period of the intercropping, the coexistence of the three grasses was observed, and it was noted that cv. BRS Zuri presented the highest population density of tillers (Table $1)$. The mean heights observed in the post-grazing were 42 and $29 \mathrm{~cm}$ for the intensities of $40 \%$ and $60 \%$, respectively. For the lower grazing intensity, the forage mass of the pseudostem was equivalent to $50 \%$ of the forage mass, and for the highest grazing intensity, the mass of dead material contributes $66 \%$ in the forage mass of the forage canopy (Table 1). In addition, Panicum maximum cv. BRS Zuri and Brachiaria brizantha cv. Xaraés have the highest tiller and pseudostem heights (Figure 2).

\section{Defoliation Pattern Among Grasses in Grazing Horizons}

The intercropping managed under a $40 \%$ grazing intensity provoked the interaction between grasses and grazing horizons for the frequency of pseudostem defoliation. In the first grazing horizon, defoliation among

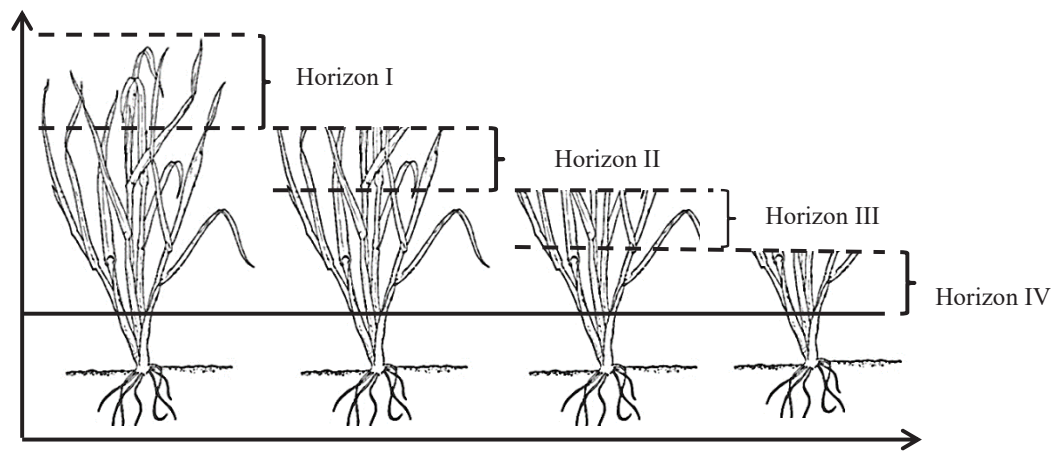

Figure 1. Representation of the molded horizon defoliation process (Adapted from Fernandes et al., 2020b). 
Table 1. Structural characteristics and management of Panicum maximum cv. BRS Zuri, Brachiaria brizantha cv. Xaraés, and Brachiaria decumbens $\mathrm{cv}$. Basilisk intercropping with $40 \%$ and $60 \%$ removals of the height of the forage canopy

\begin{tabular}{|c|c|c|c|c|}
\hline \multirow{2}{*}{ Variables } & \multicolumn{2}{|c|}{ Pre-grazing } & \multicolumn{2}{|c|}{ Post-grazing } \\
\hline & $40 \%$ & $60 \%$ & $40 \%$ & $60 \%$ \\
\hline Canopy height $(\mathrm{cm})$ & 71 & 71 & 42 & 29 \\
\hline Forage dry mass (ton/ha) & 5.0 & 4.9 & 3.3 & 2.1 \\
\hline Dry leaf lamina mass $(\%)$ & 50 & 51 & 10 & 5 \\
\hline Dry mass of pseudostem (\%) & 33 & 28 & 50 & 29 \\
\hline Dry mass of dead material (\%) & 17 & 20 & 39 & 66 \\
\hline Instantaneous stocking rate (AU $0.25 / \mathrm{ha}$ ) & 6 & 10 & - & - \\
\hline Population density of tillers (tillers/m2) & 443 & 477 & - & - \\
\hline Population density of BRS Zuri tillers (\%) & 58 & 76 & - & - \\
\hline Population density of Xaraés tillers (\%) & 37 & 19 & - & - \\
\hline Population density of Basilisk tillers (\%) & 5 & 5 & - & - \\
\hline
\end{tabular}

Note: AU= animal unit $(450 \mathrm{~kg})$.

$40 \%$ grazing intensity

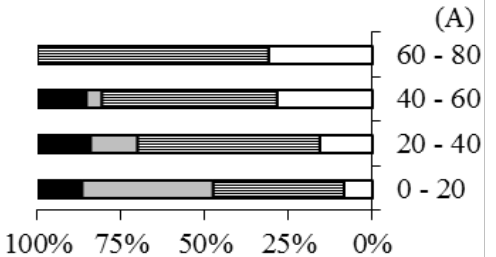

(B)
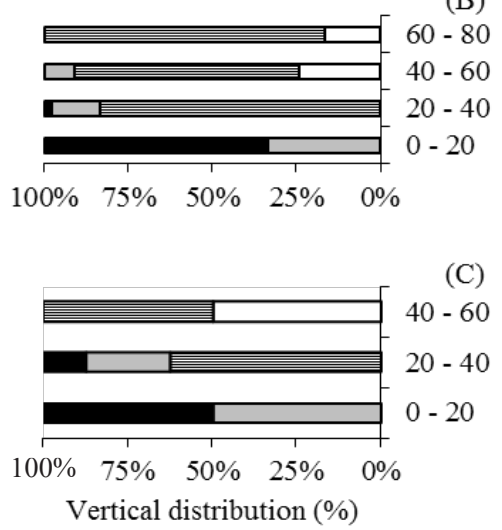

$60 \%$ grazing intensity

(D)

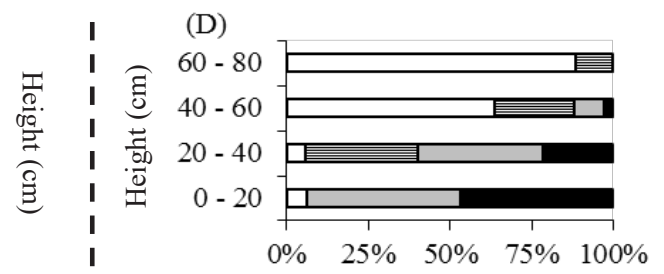

(E)

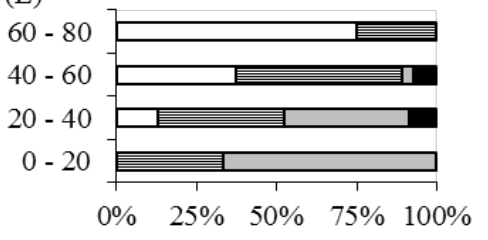

(F)

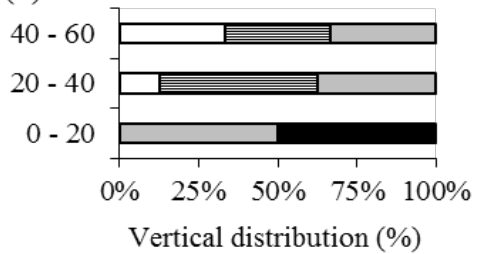

Figure 2. Vertical distribution in the pre-grazing of the botanical components of the intercropping management with 40 and $60 \%$ removal of the height of the forage canopy (Panicum maximum cv. BRS Zuri [A and D], Brachiaria brizantha $\mathrm{cv}$. Xaraés [B and E], and Brachiaria decumbens cv. Basilisk [C and F]).

$\square$ : Expanding leaf lamina; 镸: Expanded leaf lamina; $\square$ : Pseudostem; Dead material.

the intercropped grasses did not present oscillations. However, in the second horizon, the cv. Basilisk presented the highest frequency of defoliation. When the third horizon was formed, the pseudostem of cv. Xaraés was defoliated in a greater proportion. In the fourth horizon, pseudostem defoliation was similar among the species of the intercropping. The transition between grazing horizons did not modify the frequency of the pseudostem defoliation of cv. BRS Zuri (Table 2).

The intercropped pasture with $60 \%$ removal of the forage canopy height, an interaction was observed between the type of grass and the grazing horizons for the defoliation severity of the extended tiller. In the first horizon, cv. BRS Zuri presented the largest reduction of the extended tiller, whereas in the fourth horizon, the proportion of defoliation was similar to that of $\mathrm{cv}$. Basilisk (Table 2).

\section{Defoliation Pattern between the Grasses}

In the intercropping managed with $40 \%$ of the forage canopy height removal, no interaction was observed between grasses and grazing horizons for the defoliation severity of the extended tiller $(p=0.295)$, pseudostem defoliation severity $(\mathrm{p}=0.717)$, and extended tiller defoliation frequency $(p=0.624)$. However, oscillations were observed in the severity of the defoliation of the extended tiller among the intercropped species, in which the 
reduction of the tiller of the $\mathrm{cv}$. Basilisk was 32\% lower in relation to $\mathrm{cV}$. BRS Zuri. In contrast, the severity of pseudostem defoliation was similar among the species. There were also no variations in the frequency of defoliation of extended tiller between the grasses (Table 3).

In the intercropping managed with $60 \%$ of the forage canopy height removal intensity, no interaction was observed between grasses and grazing horizons for pseudostem defoliation severity $(p=0.616)$, extended tiller defoliation frequency $(p=0.351)$, and frequency of defoliation of the pseudostem tiller $(p=0.300)$. However, disproportionality was observed among the grasses because of the cv. Basilisk suffered a higher severity and frequency of pseudostem defoliation. The opposite was observed in the frequency of defoliation of the extended tiller, in which the cV. BRS Zuri and cv. Xaraés were more defoliated (Table 3).

\section{Defoliation Pattern in the Grazing Horizons}

In the grazing intensity of $40 \%$, no variation was observed for the defoliation severity of the extended tiller (Figure 3A) and pseudostem (Figure 3B) between the grazing horizons. However, the frequency of defoliation of the extended tiller was higher in the first and second horizon in relation to the other horizons (Figure 3C).
In the management with $60 \%$ of height removal, it was observed that in the third and fourth horizons, there was an increase in the severity of pseudostem defoliation (Figure 3D). The frequency of defoliation of the extended tiller presented oscillations (Figure 3E), in which the higher frequencies were observed in the first grazing horizon, followed by the second, and not different between the third and fourth grazing horizons. The frequency of pseudostem defoliations was similar in all grazing horizons (Figure 3F).

\section{DISCUSSION}

Regarding the forage mass, the two grazing intensities provided an average of $50 \%$ of leaf lamina mass in the pre-grazing (Table 1), considering that the greater supply of this morphological component was in the heights of 40 and $80 \mathrm{~cm}$ (Figure 2). In the post-grazing period, the grazing intensity of $60 \%$ promoted the lower estimates of leaf lamina mass. This condition usually occurs in the management that adopts higher stocking rates and/or strategies that aim to potentialize the use of the forage produced (Benvenutti et al., 2016; Pavetti et al., 2018; Miqueloto et al., 2020).

In both grazing intensities, the two grasses belonging to the genus Brachiaria contribute to $24 \%$ and

Table 2. Defoliation pattern of the grazing horizons of the Panicum and Brachiaria spp. intercropping managed with $40 \%$ and $60 \%$ removal of the height of the forage canopy

\begin{tabular}{|c|c|c|c|c|c|}
\hline \multirow{2}{*}{ Grazing horizon } & \multicolumn{3}{|c|}{ Cultivars of intercropped grasses } & \multirow{2}{*}{ SE } & \multirow{2}{*}{$\mathrm{p}$} \\
\hline & BRS Zuri & Xaraés & Basilisk & & \\
\hline \multicolumn{6}{|c|}{ Frequency of defoliation of pseudostem (\%) under grazing intensity of $40 \%$} \\
\hline I & $1.11^{\mathrm{Aa}}$ & $1.11^{\mathrm{Ba}}$ & $1.66^{\mathrm{Ba}}$ & 0.405 & 0.548 \\
\hline II & $1.11^{\mathrm{Ab}}$ & $2.22^{\mathrm{ABb}}$ & $5.00^{\mathrm{Aa}}$ & 0.892 & 0.003 \\
\hline III & $1.66^{\mathrm{Ab}}$ & $4.44^{\mathrm{Aa}}$ & $2.77^{\mathrm{ABab}}$ & 0.548 & 0.046 \\
\hline IV & $2.22^{\mathrm{Aa}}$ & $1.66^{\mathrm{ABa}}$ & $2.22^{\mathrm{ABa}}$ & 0.341 & 0.813 \\
\hline \multicolumn{6}{|c|}{ Severity of defoliation of the extended tiller (\%) under grazing intensity of $60 \%$} \\
\hline I & $40.72^{\mathrm{Aa}}$ & $31.06^{\text {Aab }}$ & $21.33^{\mathrm{Bb}}$ & 2.90 & $<0.001$ \\
\hline II & $31.84^{\mathrm{Aa}}$ & $32.23^{\mathrm{Aa}}$ & $27.33^{\mathrm{ABa}}$ & 2.00 & 0.385 \\
\hline III & $32.00^{\mathrm{Aa}}$ & $27.42^{\mathrm{ABa}}$ & $27.29^{\mathrm{ABa}}$ & 3.61 & 0.396 \\
\hline IV & $30.35^{\mathrm{Aa}}$ & $18.85^{\mathrm{Bb}}$ & $33.88^{\mathrm{Aa}}$ & 3.89 & 0.001 \\
\hline
\end{tabular}

Note: $a, b=$ Values within a row with different superscripts differ significantly at $p<0.05, A, B=$ Values within a column with different superscripts differ significantly at $p<0.05$. $S E=$ mean standard error, $p=$ significant effect probability of interaction between grasses and grazing horizon. Grazing horizon I= day zero to the second day of grazing, grazing horizon II= second day to the fourth day of grazing, grazing horizon III= fourth day to the sixth day of grazing, grazing horizon IV: sixth day to eighth day of grazing.

Table 3. Defoliation pattern of Panicum and Brachiaria spp. intercropping, managed with removal of $40 \%$ and $60 \%$ of the height of the forage canopy

\begin{tabular}{|c|c|c|c|c|c|}
\hline \multirow{2}{*}{ Variables } & \multicolumn{3}{|c|}{ Cultivars of intercropped grasses } & \multirow{2}{*}{ SE } & \multirow{2}{*}{$\mathrm{p}$} \\
\hline & BRS Zuri & Xaraés & Basilisk & & \\
\hline \multicolumn{6}{|c|}{$40 \%$ grazing intensity } \\
\hline Extended tiller defoliation severity (\%) & $30.77^{a}$ & $26.32^{\mathrm{ab}}$ & $20.82^{b}$ & 1.63 & 0.027 \\
\hline Severity of pseudostem defoliation (\%) & 15.33 & 10.62 & 22.26 & 2.11 & 0.102 \\
\hline Extended tiller defoliation frequency (\%) & 8.33 & 7.63 & 6.24 & 0.831 & 0.080 \\
\hline \multicolumn{6}{|c|}{$60 \%$ grazing intensity } \\
\hline Severity of pseudostem defoliation (\%) & $10.10^{\mathrm{b}}$ & $11.53^{\mathrm{b}}$ & $27.11^{\mathrm{a}}$ & 2.10 & $<0.001$ \\
\hline Extended tiller defoliation frequency (\%) & $8.05^{\mathrm{a}}$ & $8.14^{\mathrm{a}}$ & $5.55^{\mathrm{b}}$ & 0.658 & 0.005 \\
\hline Pseudostem defoliation frequency (\%) & $1.38^{\mathrm{b}}$ & $2.86^{\mathrm{ab}}$ & $3.33^{\mathrm{a}}$ & 0.338 & 0.034 \\
\hline
\end{tabular}

Note: $a, b=$ Values within a row with different superscripts differ significantly at $\mathrm{p}<0.05$. $S E=$ mean standard error, $\mathrm{p}=$ significant effect probability. 
$40 \%$ grazing intensity
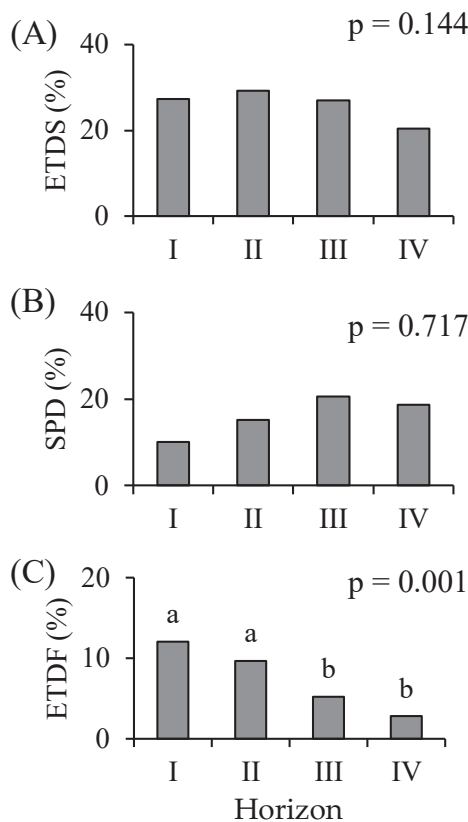

$60 \%$ grazing intensity

(D)

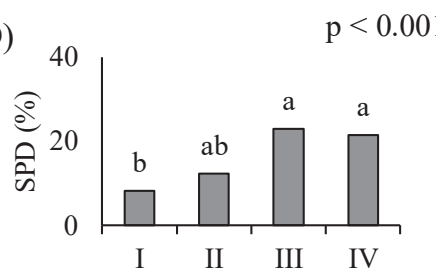

(E)

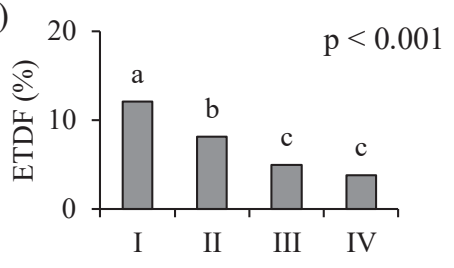

(F)

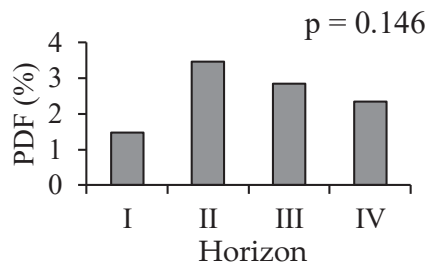

Figure 3. Grazing horizon (horizon I= day zero to the second day of grazing; horizon II= second day to the fourth day of grazing; horizon III= fourth day to the sixth day of grazing; horizon IV= sixth day to eighth day of grazing) defoliation pattern in the intercropping of Panicum and Brachiaria spp. cultivars. $40 \%$ removal of the height of the forage canopy: ETDS= extended tiller defoliation severity $(A)$, $\mathrm{SPD}=$ severity of pseudostem defoliation (B), ETDF= extended tiller defoliation frequency (C). $60 \%$ removal of forage canopy height: SPD= Severity of pseudostem defoliation (D), ETDF= extended tiller defoliation frequency $(\mathrm{E}), \mathrm{PDF}=$ pseudostem defoliation frequency $(\mathrm{F})$. Means followed by different lowercase letters in columns differ from each other by Tukey test, at $5 \%$.

$42 \%$ in the tiller density, suggesting that there is little participation of this genus in the forage mass (Table 1). However, this factor did not prevent all grasses from being grazed during the period of occupation of the paddocks, because from the first to the fourth horizon, the defoliations in all cultivars were verified (Table 2), being evident that the population density of tillers does not compromise defoliation.

On the other hand, the vertical distribution of grasses and structural components (Figure 2) can be a determinant factor in the defoliation pattern (Romera et al., 2012; Bremm et al., 2016). Therefore, the vertical distribution of the grasses allied to the grazing intensity influenced the defoliation pattern differently in the intercropping. As the horizons were molded, in the lowest grazing intensity, there were variations in the frequency of pseudostem defoliation, and when the intercropping was managed with $60 \%$ reduction of the forage canopy, the defoliation severity of the extended tiller was altered with each molded horizon (Table 2).

The intercropped pasture was managed with $40 \%$ reduction of the forage canopy, it was verified that the grasses with the highest height (Figure 2A and 2B) allowed the greater depths of defoliation, and this event occurred as the horizons were being molded. This is an indication that animals adjust the depth of defoliation (Fernandes et al., 2020b), and begin to avoid structures of the tiller that have low nutritive value (Romera et al.,
2012; Mezzalira et al., 2017), which may explain the proportionality of defoliation severity in pseudostem (Table 3 and Figure 3B).

The reduction of the height of the forage canopy, there is an increase in the supply of pseudostem (Zanini et al., 2012), leading the animal to explore the other grazing ranges to balance the rate of forage intake. This may be a factor that caused the defoliation of the Brachiaria genera (Table 2 and 3), leading to a mixed diet during the grazing events.

It is possible to infer that the animals did not distinguish and/or select the tillers of each cultivar in the intensity of $40 \%$, since the frequency of defoliation of the extended tiller was similar (Table 3). Defoliation frequency is evaluated in intercropped pastures, and inferences can be made about which species is the most selected, in addition to expressing how much the tiller and its respective components are explored throughout the grazing cycles and/or grazing horizons formation.

Therefore, when the frequency of pseudostem defoliation was analyzed, the animals manifested preference (Table 2). Consequently, when the animals began to explore the second horizon, it was understood that at the time of the bite when defoliating the cv. Basilisk, there was a higher occurrence of the pseudostem grazing of this grass. This condition may be related to the architecture of the tillers of $B$. decumbens, since this grass, in the vegetative stage, naturally presents the lighter and 
less dense tillers (Santos et al., 2010), and these characteristics promote a balance in the defoliation rates of the tiller and their respective components.

Among the tropical climate grasses, Panicum presents pseudostem with the higher concentrations of fiber and lignin in relation to the genus of Brachiaria (Fernandes et al., 2020c), which indicates a high resistance to defoliation and can form a physical barrier and hinder the deepening of the bite (Romera et al., 2012). Therefore, to avoid the reduction in the rate of forage intake between the molded horizons, the pseudostem of cv. BRS Zuri was frequently defoliated on a constant scale, which promoted the same severity of defoliation of the tiller and pseudostem among the grasses (Table 3).

As the grazing horizons were molded in the intercropping managed with $60 \%$ of forage-canopy removal, a variation in the severity of defoliation of the extended tiller to each molded horizon was observed (Table 2), because when the animals defined the first horizon, $\mathrm{cV}$. BRS Zuri and cV. Xaraés were defoliated in the greater proportions, which may be related to an easier apprehension of these grasses due to the greater height they both present (Figure 2D and 2E).

The three grasses occupied the layers of $20-40 \mathrm{~cm}$ (Figure 2D, 2E, and 2F), thus, theoretically, the accessibility was equal, allowing the same severity of defoliation of the extended tiller (Horizons II and III; Table 3). However, when horizon four was molded, the removal of plant tissue from the extended tiller was lower in $\mathrm{cv}$. Xaraés, indicating that the tillers had a length close to the post-grazing height target $(29 \mathrm{~cm}$; Table 1$)$. In this height range, probably, $B$. Brizantha contributes little to the rate of forage intake, and to compensate for this deficit, the animals exert a higher defoliation severity in the tillers of the other grasses.

On the other hand, it was evident that the management that adopted the higher stocking rate, allied to a shorter post-grazing height, impacted in preferences, since the cultivar Basilisk presented the lowest frequency of defoliation of the extended tiller (Table 2 ). One possible explanation for the occurrence of this event may be related to the shorter leaf lamina length of Brachiaria in relation to Panicum (Rodrigues et al., 2012), reducing defoliation events (Figure 3E).

In the two management proposals, how the supply and positioning of pseudostem can be determinant in the defoliation pattern in the intercropped pasture of tropical climate. Therefore, the suggestion is to adopt management with a lower grazing intensity (removal of $40 \%$ of the initial pre-grazing height), because it does not impact on the preferences between the intercropped species (Table 3) and the little contribution of pseudostem in the heights of 40-80 $\mathrm{cm}$ (Figures 2A, 2B and $2 \mathrm{C}$ ), indicating that the rate of forage intake has not been compromised (Guzatti et al., 2017; Schmitt et al., 2019).

\section{CONCLUSION}

In intercropped pastures managed under grazing intensities of $40 \%$, as the animal explores the grazing horizons, the vertical distribution of the pseudostem can modify the shape and positioning of the depth of the bite, leading the animal to perform less selective grazing among the species, although there is less preference for the pseudostem botanical component. In the grazing intensity of $60 \%$, it is possible to infer that the rate of forage intake was reduced due to the greater supply of pseudostem in the residual height, making this management practice unattractive for intercropped pastures.

\section{CONFLICT OF INTEREST}

The authors declare there is no conflict of interest with any financial, personal, or other relationships with other people or organization related to the material discussed in the manuscript.

\section{ACKNOWLEDGEMENT}

Authors thank the coordination of improvement of higher education personnel-Brazil (CAPES)-Financing Code 001 for providing the fund.

\section{REFERENCES}

Barbosa, R. A., C. Medeiro-Neto, A. H. Zimmer, M. C. M. Macedo, P. B. Fernandes, \& A. F. Sbrissia. 2018. Alternativas para o estabelecimento de consórcios de gramíneas tropicais. Comu. Tec. 147:1-18. https://doi. org/10.13140/RG.2.2.19571.14882

Benvenutti, M. A., D. R. Pavetti, D. P. Poppi, I. J. Gordon, \& C. A. Cangiano. 2015. Defoliation patterns and their implications for the management of vegetative tropical pastures to control intake and diet quality by cattle. Gras. For. Sci. 71:424-436. https://doi.org/10.1111/gfs.12186

Bremm, C., P. C. Carvalho, L. Fonseca, G. A. Amaral, J. C. Mezzalira, N. B. Perez, C. Nabinger, \& E. A. Laca. 2016. Diet switching by mammalian herbivores in response to exotic grass invasion. PLOS ONE 11: e0150167. https://doi. org/10.1371/journal.pone.0150167

Brunetti, H. B., L. D. R. Carvalho, M. B. Chiavegato, \& S. C. Da Silva. 2016. Sward structure, light interception and herbage accumulation in forage peanut cv. Belmonte subjected to strategies of intermittent grazing management. Act. Scientiar. Anim. Sci. 38:395-404.https://doi.org/10.4025/actascianimsci.v38i4.32207

Carvalho, P. C. F. 2013. Harry Stobbs Memorial Lecture: Can grazing behavior support innovations in grassland management? Trop. Gras - Forr. Trop. 1:137-155. https://doi. org/10.17138/TGFT(1)137-155

Duchini, P. G., G. C. Guzatti, J. R. Echeverria, L. F. Américo, \& A. F. Sbrissia. 2018. Can a mixture of perennial grasses with contrasting growth strategies compose productive and stable swards? Agro. J. 111: 224-232. https://doi. org/10.2134/agronj2018.03.0218

Fernandes, P. B., R. A. Barbosa, M. G. Morais, C. MedeirosNeto, H. J. Fernandes, A. L. C. Gurgel, G. S. Difante, C. M. Costa, A. F. Sbrissia, J. C. S. Santana, \& F. A. S. Silva. 2020a. Tropical forage grasses intercropped under lenient grazing intensities promote greater soil cover. J. Agri. Stu. 8: 213-223. https://doi.org/10.5296/jas.v8i2.16121

Fernandes, P. B., R. A. Barbosa, R. T. Oliveira, C. V. V. Oliveira \& C. Medeiros-Neto. 2020b. Defoliation dynamics of Brachiaria brizantha pastures with distinct structural characteristics. Biosci. J. 36:203-211. https://doi.org/10.14393/ BJ-v36n1a2020-42211

Fernandes, L. S., G. S. Difante, M. G. Costa, J. V. EmerencianoNeto, I. M. M. Araújo, J. L. S. Dantas, \& A. L. C. Gurgel. 
2020c. Pasture structure and sheep performance supplemented on different tropical grasses in the dry season. Rev. Mex. Cienc. Pec. 11:89:101. https://doi.org/10.22319/ rmcp.v11i1.5083

Ferreira, E. B., P. P. Cavalcanti \& D. A. Nogueira. 2014. ExpDes: an R Package for ANOVA and experimental designs. App. Math. 5:2952. https://doi.org/10.4236/am.2014.519280

Grace, C., T. M .Boland, H. Sheridan, S. Lott, E. Brennan, R. Fritch, \& M. B.Lynch. 2018. The effect of increasing pasture species on herbage production, chemical composition and utilization under intensive sheep grazing. Gras. Forr. Sci. 73:852-864. https://doi.org/10.1111/gfs.12379

Guzatti, G. C., P. G. Duchini, A. F. Sbrissia, J. C. Mezzalira, J. G. R. Almeida, P. C. F. Carvalho, \& H. M. N. RibeiroFilho. 2017. Changes in the short-term intake rate of herbage by heifers grazing annual grasses throughout the growing season. Grass. Sci. 63: 255-264. https://doi. org/10.1111/grs.12170

Menezes, B. B., L. M. Paiva, P. B. Fernandes, N. R. F. Campos, R. A. Barbosa, A. L. L. Bento, \& M. G. Morais. 2019. Tissue flow and biomass production of piatã grass in function of defoliation frequency and nitrogen fertilization. Colloqui. Agra. 15:92-100. https://doi.org/10.5747/ca.2019.v15. n2.a288ca

Mezzalira, J. C., O. J. Bonnet, P. C. F. Carvalho, L. Fonseca, C. Bremm, C. C. Mezzalira, \& E. A. Laca. 2017. Mechanisms and implications of a type IV functional response for short-term intake rate of dry matter in large mammalian herbivores. J. Anim. Eco. 86:1159-1168. https://doi. org/10.1111/1365-2656.12698

Miqueloto, T., C. Medeiros-Neto, C. D. M. Martins, R. A. Barbosa, S. C. Da Silva, \& A. F. Sbrissia. 2020. Herbage utilisation efficiency of continuously stocked pastures during periods of restricted pasture growth. Act. Agri. Scan., Section B-S. Plan. Sci. 70:208-214. https://doi.org/10 $.1080 / 09064710.2019 .1699157$

Montagner, D. B., D. Nascimento Júnior, H. H. Vilela, B. M. L. Sousa, V. P. B. Euclides, S. C. Da Silva, \& M. N. Carloto. 2012. Tillering dynamics in pastures of guinea grass subjected to grazing severities under intermittent stocking. R. Bras. Zootec. 3:544-549. http://dx.doi.org/10.1590/ S1516-35982012000300010
Pavetti, D. R., M. A. Benvenutti, Ó. Radke, \& Ó. A. Cibils. 2018. Evaluación de un sistema de manejo de Axonopus catarinensis en rotación basado en el remanente de forraje no pastado (Renopa). Trop. Gras. - Forr. Trop. 6:53-57. http:// dx.doi.org/10.17138/tgft(6)53-57.

Roca-Fernández, A. I., J. L. Peyraud, L. Delaby, \& R. Delagarde. 2016. Pasture intake and milk production of dairy cows rotationally grazing on multi-species swards. ANIMAL 10: 1448-1456. https://doi.org/10.1017/S1751731116000331

Rodrigues, C. S., D. Nascimento Júnior, E. Detmann, S. C. DA Silva, B. M. D. L. Sousa, \& M. C. T. Silveira. 2012. Functional clusters of tropical forage grasses. R. Bras. Zootec. 41:1385-1393. https://doi.org/10.1590/ S1516-35982012000600010

Romera, A. J., J. C. Burges, P. Gregorini, \& M. G. Agnusdei. 2012. Morphological components of Thynopirum ponticum tillers and their contribution to the diet of cattle grazing at contrasting herbage allowances. Live. Sci. 150:284-292. https://doi.org/10.1016/j.livsci.2012.09.013

Santos, M. E. R., D. M. Fonseca, E. M. Balbino, S. P. Silva, M. J. P. I. Santos, \& V. Gomes. 2010. Características estruturais de perfilhos vegetativos e reprodutivos em pastos diferidos de capim-braquiária. Ciên. Anim. Bras. 11:92-502. https://doi.org/10.5216/cab.v11i3.4957

Schmitt, D., D. A. Padilha, C. Medeiros-Neto, H. M. N. RibeiroFilho, L. E. Sollenberger, \& A. F. Sbrissia. 2019. Herbage intake by cattle in kikuyugrass pastures under intermittent stocking method. R. Ciên. Agro. 50:493-501. https://doi. org/10.5935/1806-6690.20190058

Stejskalová, M., P. Hejcmanová, V. Pavlů, \& M. Hejcman. 2013. Grazing behavior and performance of beef cattle as a function of sward structure and herbage quality under rotational and continuous stocking on species-rich upland pasture. Anim. Sci. J. 84:622-629. https://doi.org/10.1111/ asj. 12048

Zanini, G. D., G. T. Santos, D. Schmitt, D. A. Padilha, \& A. F. Sbrissia. 2012. Distribuição de colmo na estrutura vertical de pastos de capim Aruana e azevém anual submetidos a pastejo intermitente por ovinos. Ciên. R. 42:882-887. https://doi.org/10.1590/S0103-84782012000500020 